\title{
PENDEKATAN METODE BERMAIN PERAN UNTUK PENDIDIKAN SEKS ANAK USIA DINI
}

\author{
ALUCYANA \\ Pendidikan Islam Anak Usia Dini (PIAUD) Fakultas Agama Islam (FAI) \\ Universitas Islam Riau (UIR) \\ alucyana@fis.uir.ac.id
}

\begin{abstract}
Introduce early sex education is very important, so that children are able to fortify itself from sexual crimes. The impact of violence or sexual abuse on early childhood is very influential on their psychological development. Starting from the short-term impact of physical pain, guilt, fear, anxiety, shame, anger, and helplessness. While the long term is a particular psychological symptoms that the victim felt as a trauma that caused the victim to have no trust. Early childhood sex education is an attempt to provide information or knowledge to early childhood about identifying limbs, parts and limb functions, as well as the importance of maintaining limbs, as well as differences in men and women. One of the learning methods used in early childhood is learning while playing. Namely the method of pretend plays or play ostensibly. This game is very effective considering the early age has a vocabulary that is still limited and not able to think abstract to prevent the occurrence of sexual abuse in early childhood.
\end{abstract}

Keywords: role play, sex education, early childhood

\section{PENDAHULUAN}

Dewasa ini, semakin banyak kasus pelecehan seksual dan perkosaan yang menimpa anak-anak dan remaja. Kasus pelecehan seksual dan perkosaan sebagian besar menimpa anak -anak dan remaja putri. Banyak kasus pelecehan seksual dan perkosaan yang terjadi dimulai dari anak-anak yang masih dibawah umur (Anonim, 2006), pelecehan seks di sekolah (Anonim, 2006), bahkan kepala sekolah yang seharusnya memberi contoh pada murid-muridnya melakukan pelecehan seksual kepada siswi- siswinya (Anonim, 2007), walikota yang menghamili ABG (Anonim, 2007), hingga personel tentara perdamaian pun melakukan pelecehan seksual (Anonim, 2 006).

Komisioner KPAI Jasra Putra mengungkapkan, data menunjukkan bahwa pihaknya menemukan 218 kasus kekerasan seksual anak pada 2015. Sementara pada 2016, KPAI mencatat terdapat 120 kasus kekerasan seksual terhadap anakanak. Kemudian di 2017, tercatat sebanyak 116 kasus.

Pelecehan seksual adalah setiap bentuk perilaku yang memiliki 
muatan seksual yang dilakukan seseorang atau sejumlah orang namun tidak disukai dan tidak diharapkan oleh orang yang menjadi sasaran sehingga menimbulkan akibat negatif, seperti: rasa malu, tersinggung, terhina, marah, kehilangan harga diri, kehilangan kesucian, dan sebagainya, pada diri orang yang menjadi korban (Supardi \& Sadarjoen, 2006). Menurut Wahid dan Irfan (2001, dalam Abu Hurairah, 2007) kekerasan seksual merupakan istilah yang menunjuk pada perilaku seksual deviatif atau hubungan seksual yang menyimpang, merugikan pihak korban dan merusak kedamaian di tengah masyarakat.

Walaupun sebagian besar korban pelecehan seksual dan perkosaan adalah wanita, akan tetapi dalam beberapa kasus, laki-laki juga dapat menjadi korban pelecehan seksual yang umumnya dilakukan oleh laki-laki juga. Pada sebagian besar kasus, perkosaan dilakukan oleh orang yang sangat dikenal korban, misalnya teman dekat, kekasih, saudara, ayah (tiri maupun kandung), guru, pemuka agama, atasan. Sebagian kasus lainnya, perkosaan dilakukan oleh orangorang yang baru dikenal dan semula nampak sebagai orang baik-baik yang menawarkan bantuan, misalnya mengantarkan korban ke suatu tempat.

Finkelhor (1979, dalam Christopher,B and Kathleen,K, 2004) menemukan $23 \%$ anak perempuan yang berusia 7-9 tahun rentan menjadi korban perkosaan, sedangkan $32 \%$ pada anak laki-laki usia 13-16 tahun adalah usia yang rentan untuk menjadi korban perkosaan. Dilaporkan juga bahwa $47 \%$ yang menjadi mitra atau pelaku dari perkosaan tersebut adalah usia yang lebih tua dari mereka. Aktivitas seksual yang dilakukan adalah dengan membelai dan menyentuh dan $50 \%$ pelaku menggunakan gaya ancaman pada korban perkosaan.

Kekerasan terhadap anakanak yang terjadi di sekitar kita tidak saja dilakukan oleh pihak luar tetapi juga dilakukan oleh keluarga anak sendiri yakni orang tua. Kasus-kasus kekerasan yang menimpa anak-anak, tidak saja terjadi di perkotaan tetapi juga di pedesaan. Namun sayangnya belum ada data yang lengkap mengenai ini. Sementara itu, para pelaku child abuse, 68\% dilakukan oleh orang yang dikenal anak, termasuk $34 \%$ dilakukan oleh orangtua kandung sendiri (Hakim, L, 2008).

Pelecehan seksual dapat mengakibat kan sekelompok gejala psikologis khas pasca-traumatis stres (Finkelhor 1979, Russell 1986, Johnson 1987, Kilgore1988, Young, 1992, dalam Murphy.J, 2001) dan tanda-tanda non-verbal pada anak. Supardi \& Sadarjoen (2006) juga mengatakan pelecehan seksual dan perkosaan dapat menimbulkan efek trauma yang mendalam pada korban. Korban pelecehan seksual dan 
perkosaan dapat mengalami stres akibat pengalaman traumatis yang telah dialaminya. Gangguan stres yang dialami korban pelecehan seksual dan perkosaan seringkali disebut Gangguan Stres Pasca Trauma (Post Traumatic Stress Disorder atau PTSD). Efek psikologi tersebut berakibat panjang pada korban perkosaan. Gejala trauma dan perilaku ditunjukan dengan depresi, rasa bersalah, harga diri yang rendah, dan perasaan rendah diri (Meiselman 1978, dalam Christopher,B and Kathleen,K, 2004). Bahkan Runtz (1986, dalam Christopher, B and Kathleen,K, 2004) menambahkan bahwa efek dari anak-anak korban perkosaan adalah meningkatnya upaya bunuh diri dan merusak diri sendiri. (Finkelhor,1979, dalam Christopher, B and Kathleen,K, 2004) mengatakan $66 \%$ perempuan yang menjadi korban perkosaan lebih memiliki pengalaman negatif dibandingkan laki-laki yang hanya $32 \%$.

\section{Linda E. Ledray (dalam}

Susanto. I.S, 1997) melakukan penelitian mengenai gambaran penderitaan yang dialami oleh perempuan korban perkosaan. Penelitian tersebut dilakukan dengan mengambil data perempuan korban perkosaan di Amerika, yang diteliti 23 jam setelah perkosaan. Hasil yang diperoleh menyebutkan bahwa 96\% mengalami pusing; 68\% mengalami kekejangan otot yang hebat. Sementara pada periode post-rape yang dialami adalah 96\% kecemasan; 96\% rasa lelah secara psikologis; $88 \%$ kegelisahan tak henti; $88 \%$ merasa terancam dan $80 \%$ merasa diteror oleh keadaan.

Melihat begitu banyak dampak psikologis yang timbul dari anak korban perkosaan maka perlu diadakan penyembuhan atau intervensi. Menurut Sussan, G (1979, dalam Christopher, B and Kathleen, $K$, 2004) penyembuhan itu perlu dan percaya dapat menyembuhkan diri sendiri. Dawson (1983, dalam Christopher,B and Kathleen, K, 2004) menyebutkan setidaknya ada 6 tujuan terapi untuk anak-anak yang menjadi korban kekerasan seksual adalah : (1) Reduksi adalah keterlibatan dalam mengatasi rasa bersalah pengurangan rasa ketakutan tentang pelecehan berikutnya (3) resolusi perasaan yang ambivalen dalam memahami perbedaan antara perasaan dan menerima tentang sexual abuse (4) peningkatan harga diri (5) peningkatan ketrampilan asertif (6) mengajarkan seksualitas yang tepat.

Mengajarkan seksualitas yang tepat dimaksud adalah mengajarkan pendidikan seks yang tepat. Hal ini disebabkan begitu banyak dampak negatif bagi korban pelecehan seksual, maka perlu dilakukan upayaupaya pencegahan agar pelecehan seksual terutama pada anak usia dini dapat diminimalisir. Salah satu bentuk preventif yang dapat dilakukan adalah dengan 
mengajarkan pendidikan seks pada anak. Hal ini sesuai yang dikatakan oleh Jatmikowati (2015) bahwa pendidikan seks untuk anak usia dini bukan mengajarkan anak untuk melakukan seks bebas ketika mereka dewasa kelak. Pendidikan seks dimaksudkan agar anak memahami akan kondisi tubuhnya, kondisi tubuh lawan jenisnya, serta menjaga dan menghindarkan anak dari kekerasan seksual.

Pengenalan seks pada anak dapat dimulai dari pengenalan mengenai anatomi tubuh. Kemudian, meningkat pada pendidikan mengenai cara berkembangbiak makhluk hidup, pada manusia dan binatang. Sebagaimana dikemukakan Nurul Chomaria (2014), pendidikan seks diawali dengan memperkenalkan bagian tubuh. Lambat laun anak akan mengetahui bahwa vagina dan penis berfungsi tidak hanya sebagai jalan untuk buang air kecil, tetapi lebih dari itu, yakni sebagai salah satu alat untuk melakukan reproduksi.

Pendidikan seks usia dini
lebih ditekankan bagaimana memberikan pemahaman pada anak akan kondisi tubuhnya, pemahaman akan lawan jenisnya, dan pemahaman untuk menghindarkan dari kekerasan seksual. Pendidikan seks yang dimaksud di sini adalah anak mulai mengenal akan identitas diri dan keluarga, mengenal anggota tubuh mereka, serta dapat menyebutkan ciri-ciri tubuh. Cara yang dapat digunakan mengenalkan tubuh dan ciri-ciri tubuh antara lain melalui media gambar atau poster, lagu, dan permainan.

$\begin{array}{lrrr}\text { Beberapa negara di } & \text { Eropa } \\ \text { seperti Inggis dan } & \text { Irlandia } \\ \text { mendukung bermain } & \text { sebagai } \\ \text { kerangka dasar kurikulum pada }\end{array}$
pendidikan anak usia dini (Whitebread, 2010). Salah satu permainan anak usia dini yang melegenda dan terus menghasilkan banyak penelitian di seluruh disiplin ilmu adalah permainan dengan purapura (pretend play). Istilah pretend play umumnya digunakan untuk jenis permainan di mana anak-anak mulai mampu berkomunikasi secara transformatif dan secara kolektif mengubah objek, orang dan situasi dalam rangka menciptakan situasi non-literal atau 'seakan-akan'.

Telah banyak penelitian dilaksanakan dalam rangka menyelidiki peran permainan purapura untuk anak usia dini. Penelitianpenelitian tersebut berkisar mulai dari studi etnografi tentang bagaimana jenis permainan ini berkembang, bagaimana fungsi permainan ini secara spesifik dan bagaimana faktorfaktor kontekstual secara langsung ataupun tidak langsung memberikan hambatan dan dukungan terhadap perkembangan jenis permainan ini, (Ahmad Mukhlis, 2016). Melalui tulisan ini akan menguraikan salah satu tindakan preventif untuk terjadinya sexual abuse pada anak usia dini dengan metode pretend play. 
Metode ini dirasa tepat karena sesuai dengan perkembangan anak usia dini.

Pendidikan adalah proses pengubahan sikap dan tata laku seseorang atau kelompok orang dalam usaha mendewasakan manusia melalui upaya pengajaran dan pelatihan. Sadulloh (2012) menjelaskan bahwa pendidikan mengandung suatu pengertian yang sangat luas, menyangkut seluruh aspek kepribadian manusia. Pendidikan menyangkut hati nurani, nilai-nilai, perasaan, pengetahuan dan keterampilan. Pendidikan pada hakikatnya akan mencakup kegiatan mendidik, mengajar, dan melatih. Ketiga, kegiatan tersebut harus berjalan secara terpadu dan berkelanjutan serta serasi dengan perkembangan peserta didik

dan lingkungan hidupnya guna

untuk mentransformasikan nilainilai.

Nugraha (2016) mengatakan bahwa seks berarti perbedaan tubuh laki-laki dan perempuan atau biasa disebut jenis kelamin. Sedangkan, Organisasi Perkumpulan Keluarga Berencana Indonesia Daerah Istimewa Yogyakarta (PKBI DIY) menjelaskan bahwa seks adalah perbedaan badani atau biologis perempuan dan laki-laki, yang sering disebut jenis kelamin. Hal ini senada dengan pendapat Handayani (2008), dimana seks secara umum adalah jenis kelamin yang membedakan secara biologis dan ada dua macam seks (jenis kelamin), yaitu laki-laki dan perempuan.

The National for the Education of Young Children (NAEYC) mendefinisikan anak usia dini merupakan anak yang berada pada rentang usia 0 (sejak lahir) sampai usia 8tahun. Sedangkan, menurut Nurhasmah (2015) menjelaskan bahwa: Anak usia dini adalah anak yang berusia 0-6 tahun yang memiliki karakteristik tertentu yang khas, tidak sama dengan orang dewasa dan bersifat egosentris, memiliki rasa ingin tahu yang ilmiah, unik, kaya imajinasi dan merupakan masa yang paling potensial untuk belajar. Sujiono (2009) menjelaskan bahwa anak usia dini adalah sosok individu yang sedang menjalani suatu proses perkembangan dengan pesat dan fundamental bagi kehidupan selanjutnya. Hal ini senada dengan pendapat (Semiawan, 2002) yang menjelaskan bahwa pada masa usia lima tahun pertama, perkembangan otak seorang anak sangatlah pesat, terlebih lagi pada usia 2-5 tahun yang sering disebut masa kritis pertama.

Mengenalkan pendidikan seks sejak dini sangatlah penting, agar anak mampu membentengi dirinya dari kejahatan seksual. Nawita (2013) menjelaskan bahwa pendidikan seks adalah sebagai berikut: "Pendidikan seks tidak lain adalah penyampaian informasi mengenai pengenalan (nama dan fungsi) anggota tubuh, pemahaman perbedaan jenis kelamin, penjabaran perilaku (hubungan dan 
keintiman) seks, serta pengetahuan tentang nilai dan norma yang ada di masyarakat berkaitan dengan gender." Nurhasmah (2015: 15) merangkum pengertian pendidikan seks sebagai berikut :

a. Rahmah menjelaskan bahwa pendidikan seks adalah upaya memberikan pengetahuan tentang nama-nama anggota tubuh dan termasuk alat kelamin.

b. Rimm menjelaskan bahwa pendidikan seks sederhana diberikan kepada anak usia prasekolah adalah mengidentifikasi bagian-bagian tubuh, yaitu dengan mengajarkan mengenai alat-alat kelamin bersamaan dengan memperkenalkan bagian-bagian tubuh lain seperti mata, telinga, dan tangan.

c. Nurhasmah sendiri menjelaskan bahwa pendidikan seks pada anak usia dini ialah mengajarkan dan memberikan pengetahuan mengenai jenis kelamin dan memperkenalkan anggota tubuhnya agar anak dapat memahami serta mengidentifikasi bagian-bagian tubuhnya.

Berdasarkan beberapa definisi diatas, dapat disimpulkan bahwa pendidikan seks pada anak usia dini adalah upaya untuk pemberian informasi atau pengetahuan kepada anak usia dini mengenai mengidentifikasi anggota tubuh, bagian dan fungsi anggota tubuh, serta pentingnya menjaga anggota tubuh, serta perbedaan laki-laki dan perempuan.

Metode adalah cara yang digunakan untuk mempraktekkan rencana yang sudah disusun dalam kegiatan nyata agar tujuan yang telah disusun tercapai secara optimal (Wina Sanjaya, 2008). Sebagai konstruksi teoritis, tindakan berpura-pura (the act of pretence) didefinisikan sebagai non-literal, perilaku 'seakan-akan'. Berbagai budaya mengenal berbagai jenis permainan yang kemudian bermuara secara teoritis dalam jenis permainan berpura-pura (pretend play) seperti bermain simbolik (symbolic play), bermain peran (roleplay), bermain imajinatif (imaginative play), bermain membuat-percaya (make-believe play), bermain fantasi (fantasy play), bermain dramatis (dramatic play) dan sosiodrama (sociodrama).

Sejauh ini, istilah-istilah tersebut di atas masih digunakan secara bergantian dan tidak memiliki perbedaan teoritis yang cukup jelas dan objektif, tergantung pada konteks dimana permainan tersebut digunakan.

Garvey (1990) menyebut permainan berpura-pura mewajibkan pemainnya untuk memiliki dayaatribusi dari setiap properti yang digunakan. Jarrold, Carruthers, Smith, dan Boucher (1994) menambahkan bahwa pretend play baik itu dilakukan secara individu maupun secara sosial belum tentu mewakili karakter yang diinginkan, 
namun kesemuanya tetap membutuhkan kemampuan representasional untuk membuat sebuah permainan dianggap sebagai 'pura-pura'.

Jenis kelamin anak berpengaruh dalam pemilihan permainan pura-pura. Usia anak juga memiliki efek dalam pada permainan pura-pura. Anak yang sulit berpurapura akan kesulitan melakukan berpura-pura bermain (Dewi Retno Suminar dan Dicky Hastjarjo, 2016).

Sexual abuse adalah setiap perilaku yang memiliki muatan seksual yang dilakukan seseorang atau sejumlah orang namun tidak disukai dan tidak diharapkan oleh orang yang menjadi sasaran sehingga menimbulkan akibat negatif. Seperti: rasa malu, tersinggung, terhina, marah, kehilangan harga diri, kehilangan kesucian, dan sebagainya pada diri orang yang menjadi korban (Supardi \& Sadarjoen, 2006). Sedangkan menurut Wahid dan Irfan (dalam Abu Hurairah, 2007) istilah ini menunjuk pada perilaku seksual deviatif atau hubungan seksual yang menyimpang, merugikan pihak korban dan merusak kedamaian di tengah masyarakat.

Selanjutnya Kilgore (dalam Murphy. J, 2001) mengatakan sexual abuse pada anak adalah kekerasan seksual yang dapat mencakup kontinum perilaku seksual dari paparan alat kelamin melalui kontak fisik invasif seperti penetrasi pada anus atau vagina.
Kekerasan seksual pada anak biasanya melibatkanorang dewasa. Dimana sipelaku biasanya seseorang yang memiliki kedekatan atau keterkaitan dengan anak yang dengan otoritasnya dapat melakukan pemaksaan kepada si anak melakukan aktivitas seksual. Selanjutnya sipelaku memberikan berbagai ancaman ataupun bujukan kepada korbannya agar tidak buka mulut kepada siapapun. Kekerasan seksual dapat melibatkan satu anak atau lebih. (Malchiodi dalam Murphy. J, 2001). Berdasarkan

beberapa pandangan di atas, maka dapat disimpulkan bahwa sexual abuse adalah tindakan pemaksaan hubungan seksual dari laki-laki kepada perempuan yang disertai ancaman secara fisik maupun secara psikologis. Sedangkan sexual abuse pada anak adalah tindakan pemaksaaan hubungan kelamin yang dilakukan oleh orang dewasa kepada anak yang disertai ancaman secara fisik maupun psikologis

\section{Klasifikasi sexual abuse}

Menurut Resna dan Darmawan (dalam Hurairah 2007) bahwa kekerasan seksual dapat dibagi atas tiga kategori yaitu : perkosaan, inces dan eksploitasi. Untuk lebih jelasnya dapat diuraikan sebagai berikut :

\section{a. Perkosaan.}

Pelaku tindakan perkosaan biasanya pria. Perkosaan seringkali terjadi diawali terlebih dahulu dengan ancaman. Jika korban diperiksa dengan segera setelah pemerkosaan, 
maka akan ditemukan bukti fisik seperti air mani, darah dan luka memar. Apabila kasus perkosaan dengan kekerasan terjadi kepada anak, akan menimbulkan resiko besar karena perkosaan sering berdampak pada tidak stabilnya emosi anak.

\section{b. Inces}

Inces didefinisikan sebagai hubungan seksual atau aktifitas seksual antara individu yang mempunyai hubungan dekat, dimana perkawinan di antara mereka dilarang oleh hukum maupun kultur. Inces biasanya terjadi dalam kurun waktu yang lama dan sering menyangkut suatu proses terkondisi.

\section{c. Eksploitasi.}

Eksploitasi seksual meliputi prostitusi dan pornografi. Pada beberapa kasus khususnya prostitusi ikut terlibat di dalamnya seluruh anggota keluarga seperti ibu, ayah dan anak-anaknya. Hal ini merupakan situasi patologi dimana kedua orang tua sering terlibat kegiatan seksual bersama dengan anak-anaknya dan mempergunakan anak-anak untuk prostitusi dan pornografi. Eksploitasi anak-anak membutuhkan intervensi dan penanganan yang banyak secara psikiatri.

\section{Dampak sexual abuse pada} anak.

Ada bukti yang menunjukan bahwa jika kekerasan seksual dilakukan pada anak usia dini, sangat mungkin menimbulkan sindrom traumatis jangka panjang yang membutuhkan bantuan psikiater pada beberapa waktu (Herman dalam Murphy.J, 2001). Efek awal pada anak-anak yang mengalami kekerasan seksual dapat menimbulkan kecemasan, depresi, citra diri yang buruk, isolasi, ledakan kemarahan dan permusuhan kepada orang lain. Kekerasan seksual juga akan mengakibatkan gejala khas dari PTSD (Finkelhor, Russel, Jhonson, Kilgore, Young, dalam Murphy. J, 2001).

Bagley dan Ramsay (dalam Christopher, B dan Kathleen. K, 2004)

menambahkan bahwa dampak lain dari kekerasan seksual pada anakanak adalah adanya peningkatan dorongan untuk melakukan suicide (bunuh diri) dan melakukan upaya merusak diri sendiri. Selain itu, anakanak yang mengalami kekerasan seksual juga berdampak pada perasaan marah. Ekspresi kemarahan dilakukan dalam berbagai bentuk variasi. Mereka mungkin menginternalisasi kemarahan tersebut pada diri sendiri yang berakibat depresi dan menyakiti diri sendiri atau mengekternalisasi kemarahan dengan perilaku agresif terhadap orang lain.

\section{PEMBAHASAN}

Seksualitas merupakan sebuah proses sosial-budaya yang mengarahkan hasrat atau birahi manusia. Keberadaannya dipengaruhi oleh interaksi faktor-faktor biologis, psikologis, sosial,ekonomi, politik, agama dan spritualitas. Seksualitas 
merupakan hal yang positif, berhubungan dengan jati diri seseorang dan kejujuran seseorang terhadap dirinya. Sayangnya masyarakat umumnmya masih melihat seksualitas sebagai hal negatif, bahkan tabu dibicarakan. Inilah yang membuat perbincangan mengenai seksualitas masih terbatas pada ruang tertentu dan oleh kalangan tertentu pula (Kusumaningtyas dan Ahmad Nurcholis, dkk, 2015).

Berbicara mengenai seks merupakan bagian yang alami dalam kehidupan manusia. Sebab Tuhan menciptakan manusia sebagai makhluk seks (berjenis kelamin), dan menciptakan seksual dalam mempertahankan kelangsungan eksistensi umat manusia. Namun demikian terkadang ada sebagian orang mengalami orientasi seks yang keliru hingga pelampiasan kebutuhan seksualnya condong kepada pelecehan bahkan penyiksaan pada anak. (Syarifah Fauzi'ah, 2016).

Kasus kekerasan seksual terhadap anak merupakan salah satu kasus yang mengalami peningkatan secara signifikan belakangan ini. Tidak saja meningkat secara kuantitatif tapi juga secara kualitatif. Dari waktu ke waktu kekerasan terhadap anak jumlahnya tak terbendung dan modus operandinya pun semakin tidak berperikemanusiaan.

Kuantitas kekerasan seksual terhadap anak, akhir-akhir ini sangat mengkhawatirkan. Berdasarkan pengamatan dan pendampingan Yayasan KAKAK khususnya pada kasus kekerasan seksual terhadap anak di Eks-Karesidenan Surakarta selama 3 tahun terakhir (periode 2005-2008), anak korban kekerasan seksual berjumlah 73 anak (Sari, 2009).

Berdasarkan sejumlah studi kasus 1 dari 3 wanita dan 1 dari 6 pria pernah mengalami pelecehan seksual pada masa kanak-kanak. Fenomena tersebut menunjukkan tingginya angka prevalensi pelecehan seksual pada anak (Etherington,2000; Morris, 2006; Lipovsky \& Hanson, 2007).

Kekerasan seksual dapat mengakibatkan beberapa gejala psikologis khas pasca-traumatis stres pada anak (Russell, Johnson, Kilgore, Young dalam Murphy. J, 2001). Supardi \& Sadarjoen (2006) juga mengatakan kekerasan seksual dapat menimbulkan efek trauma yang mendalam pada korban. Korban kekerasan seksual dapat mengalami stres akibat pengalaman traumatis yang telah dialaminya. Gangguan stres yang dialami korban kekerasan seksual seringkali disebut Gangguan Stres Pasca Trauma (Post Traumatic Stress Disorder atau PTSD).

Dampak psikologi tersebut berakibat panjang pada korban. Gejala trauma dapat terlihat pada perilaku seperti depresi, rasa bersalah, harga diri yang rendah, dan perasaan rendah diri (Meiselman dalam Christopher,B and Kathleen,K, 2004). Bahkan Runtz (dalam 
Christopher, B and Kathleen, K, 2004) menambahkan bahwa dampak kekerasan seksual pada anak-anak adalah meningkatnya upaya bunuh diri dan merusak diri sendiri. Finkelhor, dalam Christopher, B and Kathleen, K, (2004) mengatakan 66\% perempuan yang menjadi korban kekerasan seksual lebih memiliki pengalaman negatif lebih lama dibandingkan laki-laki yang hanya $32 \%$.

Linda E. Ledray (dalam Susanto. I.S, 1997) melakukan penelitian mengenai gambaran penderitaan yang dialami oleh perempuan korban kekerasan seksual di Amerika yang ditelitinya 2-3 jam setelah perkosaan. Hasil yang diperoleh menyebutkan bahwa 96\% mengalami pusing; $68 \%$ mengalami kekejangan otot yang hebat. Sementara pada periode post-rape yang dialami adalah $96 \%$ kecemasan; 96\% rasa lelah secara psikologis; $88 \%$ kegelisahan tak henti; $88 \%$ merasa terancam dan $80 \%$ merasa diteror oleh keadaan.

Secara umum peristiwa tersebut bisa menimbulkan dampak jangka pendek maupun jangka panjang. Keduanya merupakan suatu proses adaptasi setelah seseorang mengalami peristiwa traumatis (Hayati, 2000). Korban kekerasan seksual kemungkinan mengalami stres pasca perkosaan. Stres tersebut dapat dibedakan menjadi dua (2), yaitu stres yang langsung terjadi dan stres jangka panjang. Stres yang langsung terjadi merupakan reaksi pasca perkosaan seperti kesakitan secara fisik, rasa bersalah, takut, cemas, malu, marah, dan tidak berdaya. Sedangkan stres jangka panjang merupakan gejala psikologis tertentu yang dirasakan korban sebagai suatu trauma yang menyebabkan korban tidak memiliki rasa percaya diri, konsep diri yang negatif, menutup diri dari pergaulan, dan juga menimbulkan reaksi somatik seperti jantung berdebar dan keringat berlebihan.

Burgess dan Holmstrom (dalam Christopher,B and Kathleen,K, 2004) menyebutkan gejala yang khas dari trauma korban kekerasan seksual adalah shock, takut dan reaksi emosional yaitu kemarahan dan menyalahkan diri sendiri. Kemarahan yang terpendam yang tidak dapat mereka keluarkan, mereka alihkan dengan melukai diri sendiri dengan senjata tajam di sekujur tubuh mereka. Perasaan marah dan dendam juga mereka lampiaskan pada objek-objek di sekitar mereka.

Melihat begitu besar dampak psikologis yang timbul pada anak korban kekerasan seksual maka perlu ada tindakan intervensi oleh tenaga profesional diantaranya penggunaan terapi. Menurut Giarretto (dalam Christopher, B and Kathleen,K, 2004) ada empat tujuan terapi bagi anakanak yang menjadi korban kekerasan seksual yaitu sebagai katarsis emosi, konfrontasi, identifikasi diri dan 
manajemen diri. Katarsis emosi maksudnya adalah sebagai proses pelepasan emosi yang terpendam, perasan putus asa, malu dan perasaan bersalah. Setelah menjalani terapi memungkinkan korban keluar dari beban emosi yang terpendam dan dapat melanjutkan kehidupan mereka secara normal. Konfrontasi adalah untuk mengeksplorasi atau mengekpresikan perasaan yang terpendam sehingga dapat diketahui apa yang dirasakan selanjutnya dilakukan penanganannya. Identifikasi diri maksudnya melalui terapi korban berusaha mengenal dan memahami kepribadiannya. Proses ini diperlukan sebagai dasar bagi pengembangan konsep diri. Manajemen diri atau pengelolaan diri adalah proses belajar untuk mengontrol diri dan bertanggung jawab atas jalan hidupnya sendiri.

Dawson (dalam Christopher, B and Kathleen,K, 2004) menyebutkan setidaknya ada enam (6) tujuan terapi untuk anak-anak yang menjadi korban kekerasan seksual yaitu : (1) Reduksi adalah keterlibatan dalam mengatasi rasa bersalah (2) pengurangan rasa ketakutan terhadap kekerasan seksual berikutnya (3) resolusi perasaan yang ambivalen dalam memahami perbedaan antara perasaan dan menerima tentang sexual abuse (4) peningkatan harga diri (5) peningkatan ketrampilan asertif (6) mengajarkan seksualitas yang tepat.
Mengajarkan seksualitas yang tepat dimaksud adalah mengajarkan pendidikan seks yang tepat. Hal ini disebabkan begitu banyak dampak negatif bagi korban pelecehan seksual, maka perlu dilakukan upayaupaya pencegahan agar pelecehan seksual terutama pada anak usia dini dapat diminimalisir. Salah satu bentuk preventif yang dapat dilakukan adalah dengan mengajarkan pendidikan seks pada anak. Hal ini sesuai yang dikatakan oleh Tri Endang Jatmikowati, dkk (2015) bahwa pendidikan seks untuk anak usia dini bukan mengajarkan anak untuk melakukan seks bebas ketika mereka dewasa kelak. Pendidikan seks dimaksudkan agar anak memahami akan kondisi tubuhnya, kondisi tubuh lawan jenisnya, serta menjaga dan menghindarkan anak dari kekerasan seksual.

Sekolah dan keluarga dapat memainkan peran penting dalam memberikan pendidikan seks kepada anak-anak. Hasil penelitian yang dilakukan oleh $\mathrm{N}$ Abolghasemi, E Merghati Khoei, H Taghdissi (2013) menemukan bahwa sekolah dan keluarga merupakan institusi penting dalam memberikan pendidikan seks pada anak, Namun, guru tidak cukup kompeten dalam memberikan pendidikan perilaku seks. Kebijakan yang tidak tepat, batasan sumber daya, dan struktur budaya keluarga merupakan hambatan dalam 
pendidikan seks anak-anak di sekolah.

Mengajarkan pendidikan seks pada anak usia dini perlu memperhatikan karakteritik anak usia dini dan model pembelajaran anak usia dini itu sendiri, agar informasi yang mereka terima dapat terserap dengan baik. Berdasarkan Peraturan mentri Pendidikan dan Kebudayaan No. 146 Tahun 2014 tentang kurikulum 2013 pendidikan anak usiadini, adapun prinsip yang digunakan dalam proses pembelajaran AUD yaitu:

1) Belajar melalui bermain

Anak di bawah usia 6 tahun berada pada masa bermain. Pemberian rangsangan pendidikan dengan cara yang tepat melalui bermain, dapat memberikan pembelajaran yang

bermakna pada anak.

2) Berorientasi pada perkembangan anak

Pendidik harus mampu mengembangkan semua aspek perkembangan sesuai dengan tahapan usia anak.

3) Berorientasi pada kebutuhan anak. Pendidik harus mampu memberi rangsangan pendidikan atau stimulasi sesuai dengan kebutuhan anak, termasuk anak-anak yang mempunyai kebutuhan khusus.

4) Berpusat pada anak

Pendidik harus menciptakan suasana yang bisa mendorong semangat belajar, motivasi,minat, kreativitas, inisiatif, inspirasi, inovasi, dan kemandirian sesuai dengan karakteristik,minat, potensi, tingkat perkembangan, dan kebutuhan anak.

Dengan mengacu pada metode pembelajaran anak usia dini salah satunya adalah belajar sambil bermain, maka pendidikan seks anak usia dini dapat dilakukan dengan metode belajar sambil bermain. Beberapa negara di Eropa seperti Inggis dan Irlandia mendukung bermain sebagai kerangka dasar kurikulum pada pendidikan anak usia dini (Whitebread, 2010).

Salah satu permainan anak usia dini yang melegenda dan terus menghasilkan banyak penelitian di seluruh disiplin ilmu adalah permainan dengan purapura (pretend play). Istilah pretend play umumnya digunakan untuk jenis permainan di mana anak-anakmulai mampu berkomunikasi secara transformatif dan secara kolektif mengubah objek, orang dan situasi dalam rangka menciptakan situasi non-literal atau 'seakan-akan'.

Telah banyak penelitian dilaksanakan dalam rangka menyelidiki peran permainan purapura untuk AUD. Penelitianpenelitian tersebut berkisar mulai dari studi etnografi tentang bagaimana jenis permainan ini berkembang, bagaimana fungsi permainan ini secara spesifik dan bagaimana faktorfaktor kontekstual secara langsung ataupun tidak langsung memberikan 
hambatan dan dukungan terhadap perkembangan jenis permainan ini (Ahmad Mukhlis, 2016).
Beberapa

penelitian sebelumnya telah melakukan metode pretend play ini untuk anak usia dini diantaranya :

Tabel 1.Hasil Penelitian yang Menggunakan Metode Metode Pretend Play

\begin{tabular}{|c|c|c|c|c|}
\hline No & Tahun & Judul penelitian & Peneliti & $\begin{array}{c}\text { Subyek } \\
\text { Penelitian }\end{array}$ \\
\hline 1 & 1989 & $\begin{array}{l}\text { The Language of } \\
\text { Pretend Play. }\end{array}$ & $\begin{array}{l}\text { Garvey, C. \& } \\
\text { Kramer, T.L }\end{array}$ & $\begin{array}{l}\text { Anak } \\
\text { prasekolah }\end{array}$ \\
\hline 2 & 1997 & $\begin{array}{l}\text { Pengaruh "Permainan Pura-Pura" } \\
\text { Terhadap Perkembangan Bahasa } \\
\text { dan Kematangan Sosial Anak-Anak } \\
\text { Prasekolah }\end{array}$ & Suminar, D.W. & $\begin{array}{l}\text { Anak } \\
\text { prasekolah }\end{array}$ \\
\hline 3 & 1998 & $\begin{array}{l}\text { The Influence of Culture on Pretend } \\
\text { Play: the Case of Mennonite Children }\end{array}$ & $\begin{array}{lr}\text { Kreppner, } & \text { J.M., } \\
\text { O’Connor, } & \text { T.G., } \\
\text { Dunn, J., } & \& \\
\text { Anderson-Wood, L }\end{array}$ & $\begin{array}{l}\text { Anak } \\
\text { prasekolah }\end{array}$ \\
\hline 4 & 1999 & $\begin{array}{l}\text { The Pretend and Social } \\
\text { Role Play of Children Exposed to Early } \\
\text { Severe Deprivation }\end{array}$ & 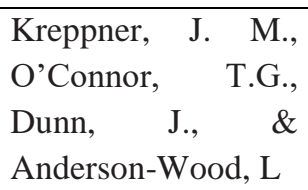 & $\begin{array}{l}\text { Anak } \\
\text { prasekolah }\end{array}$ \\
\hline 5 & 1999 & $\begin{array}{l}\text { The Effects of Storytelling and Pretend } \\
\text { Play on Cognitive Processes, Short-term } \\
\text { and Long-term Narrative Recall }\end{array}$ & Sook-Yi Kim & $\begin{array}{l}\text { Anak } \\
\text { prasekolah }\end{array}$ \\
\hline 6 & 1999 & $\begin{array}{l}\text { Preschoolers' pretend Play and Theory } \\
\text { of Mind: The role of Jointly constructed } \\
\text { presence }\end{array}$ & Schwebel, D.C & $3-5$ tahun \\
\hline 7 & 1999 & $\begin{array}{l}\text { Pretend play: Longitudinal prediction of } \\
\text { creativity and Affect in Fantasy in } \\
\text { Children }\end{array}$ & $\begin{array}{l}\text { Russ, S.W.,Robins, } \\
\text { A.L. \& Christiano, } \\
\text { B.A }\end{array}$ & $\begin{array}{l}\text { Kelas } 5-6 \\
\text { SD }\end{array}$ \\
\hline 8 & 2003 & $\begin{array}{l}\text { Cognitive Underpinning of pretend Play } \\
\text { in Autism }\end{array}$ & $\begin{array}{l}\text { Rutherford, M.D. } \\
\text { \& Rogers, S.J }\end{array}$ & $12-47$ bulan \\
\hline 9 & 2003 & $\begin{array}{l}\text { Play and Creativity: Developmental } \\
\text { Issues }\end{array}$ & Russ, S.W & $4-5$ tahun \\
\hline
\end{tabular}




\section{PENUTUP}

Kasus kekerasan seksual terhadap anak merupakan salah satu kasus yang mengalami peningkatan secara signifikan belakangan ini. Tidak saja meningkat secara kuanititas namun juga secara kualitas. Dikatakan bahwa pelaku kekerasan pada anak usia dini ini dilakukan oleh orang orang terdekat yang kadang pelakunya adalah orang yang seharusnya bertanggungjawab atas kehidupan masa depan anak tersebut seperti, ayah, abang kandung. Dampak dari kekerasan atau sexual abuse pada anak usia dini sangat berpengaruh pada perkembangan psikologis mereka. Mulai dari dampak jangka pendek berupa kesakitan secara fisik, rasa bersalah, takut, cemas, malu, marah, dan tidak berdaya. Sedangkan jangka panjang merupakan gejala psikologis tertentu yang dirasakan korban sebagai suatu trauma yang menyebabkan korban tidak memiliki rasa percaya diri, konsep diri yang negatif, menutup diri dari pergaulan, dan juga menimbulkan reaksi somatik seperti jantung berdebar dan keringat berlebihan.

Mengingat begitu beratnya damapak yang akan dialami oleh anak korban sexual abuse, maka perlu dilakukan tindakan preventif, guna mencegah agar korban sexual abuse tidak terus bertambah. Ssalah satu tindakan preventif dalam meminimalisir terjadinya sexual abuse pada anak usia dini adalah memberikan pendidikan seks. Dalam memberikan pendidikan seks pada anak usia dini perlu memeprhatikan karakteristik dan metode pembelajaran anak usia dini, agar informasi yang diberikan dapat diserap dengan baik. Salah satu metode pembelajaran yang digunakan pada anak usia dini adalah belajar sambil bermain. Bermain yang paling poluler di kalangan anak usia dini adalah metode pretend play atau bermain pura-pura. Permainan ini sangat efeketif mengingat usia anak dini memiliki perbendaharaan kata yang masih terbatas dan belum mampu berfikir abstrak. Pendidikan seks pada anak usia dini dapat dilakukan dengan metode pretend play untuk mencegah terjadinya sexual abuse pada anak usia dini.

\section{DAFTAR PUSTAKA}

Abolghasemi N, Merghati Khoei E, Taghdissi H, 2013, Teachers' perceptions of sex education of primary school children, Mendeley, Volume 8, Issue 2 (21 2010)

Abu Hurairah, 2007, Child Abuse (Kekerasan pada Anak) edisi revisi. Bandung; Penerbit Nuansa.

AD Kusumaningtyas dan Ahmad Nurcholis, 2015 Seksualitas dan 
Agama: Kesehatan Reproduksi dalam Perspektif AgamaAgama, Jakarta: Gramedia.

Akhmad Mukhlis, 2016, Metakomunikasi Anak Usia Dini: Analisis dari Permainan Sosial Berpura-Pura, Pontianak, Book One International Prooceeding Seminar "Pengembangan Potensi Anak Usia Dini”"

Anonim, "Diknas akan Periksa Kepala Sekolah Penggerayang Siswinya, http://www.rileks.com/ragam/d etnews/8052007060151.html, diakses 17 Mei 2007a.

Anonim, "Besok, Jaksa Baca Dakwaan Pelecehan Seksual di bawah Umur."

Bagley, Christoper \&King Katheleen, 2004. Child Sexual Abuse The Search for Healing, 29 West 35th Street, Inc.

Dewi Retno Suminar. Th. Dicky Hastjarjo, 20016, A Theoritical Model of Theory of Mind and Pretend Play, International Journal of Applied Psychology 2016, 6(4): p.85-93 DOI: 10.5923/j.ijap.20160604.02

Garvey, C. (1990). Play.Cambridge, MA: Harvard University Press.

Hakim, L, 2008, Kajian Kriminologis Kekerasan Terhadap Wanita, dalam Eko Prasetyo dan Suparman Marzuki, ed. Perempuan Dalam Wacana Perkosaan, Jurnal Equality, Vol. 13 No. 1 Februari 2008.
Handayani, Alva dan Aam Amiruddin. 2008. Anak Anda Bertanya Seks?: Langkah Mudah Menjawab Pertanyaan Anak tentang Seks. Bandung: Khazanah.

Jarrold, C., Carruthers, P., Smith, P.K., \& Boucher, J. (1994). Pretend play: Is it metarepresentational Mind and Language, 9(4), 445-467.

Kesehatan/news/0409/12/201621.ht ml, diakses 05 Desember 2006.

Morris, R. (2006). Understanding child sexual abuse.62nd Annual IARCCA Conference Indianapolis.

Murphy.J. 2001. Art Therapy with Young Survivors of Sexual Abuse Lost for Words. Simultaneously published in the USA and Canada by Taylor \& Francis Inc.

Nawita, Muslik. 2013. Bunda, Seks itu Apa?: Bagaimana Menjelaskan Seks padaAnak. Bandung: Yrama Widya.

Nurhasmah, Wini. 2015. Implementasi Pendidikan Seksual untuk Anak Usia Dini.Skripsi. Bandung: UPI.

Nurul Chomaria. 2014.Pelecehan Anak, Kenali dan Tangani; Menjaga Buah Hati dari Sindrom.Cet. I: Solo: Tinta Medina.

Peraturan Menteri Pendidikan dan Kebudayaan nomor. 146 Tahun 2014 tentang Kurikulum 2013 Pendidikan Anak Usia Dini. 
Sadulloh, Uyoh. 2012. Pengantar Filsafat Pendidikan. Bandung: Alfabeta.

Sari, A. P. (2009) Penyebab Kekerasan Seksual terhadap Anak dan Hubungan Pelaku dengan Korban. Diunduh tanggal 27 Juli 2009 dari http://kompas.com/index.php/r ead/xml/2009/01/28/

Semiawan, Conny. R. 2002. Belajar dan Pembelajaran dalam Taraf Usia Dini. Jakarta: Ikrar Mandiri Abadi.

Sujiono, Yuliani Nurani. 2009. Konsep Dasar Pendidikan Anak Usia Dini. Jakarta: Indeks.

Suminar, D.R. (1997).Pengaruh "Permainan Pura-Pura" Terhadap Perkembangan Bahasa dan Kematangan Sosial Anak-anak Prasekolah. Thesis. Yogjakarta: Universitas Gadjah Mada.

Supardi, S.\& Sadarjoen, "Dampak Psikologis Pelecehan Seksual pada Anak Perempuan", http://www.kompas.com/

Susanto, I. S. 1997.Perempuan Dalam Wacana Perkosaan,
Yogyakarta: Perkumpulan Keluarga Berencana Indonesia

Syarifah Fauzi'ah, 2016, Faktor Penyebab Pelecehan Seksual Terhadap Anak, Jurnal Annisa', Volume 9 Nomor 2 Desember 2016, Makassar: Uin Alauddin.

Tri Endang Jatmikowati, dkk, 2015.Model dan Materi Pendidikan Seks Anak Usia Dini Perspektif Gender untuk Menghindarkan Sexual Abuse. Jurnal Cakrawala Pendidikan, Oktober 2015, Th. XXXIV, No. 3,Jember: FKIP Universitas Muhammadiyah Jember

Whitebread, D. (2010). Play, metacognition and selfregulation. In P. Broadhead, J. Howard, \& E.Wood (Eds.), Play and learning in the early years (pp. 161-176). London, UK: Sage.

Wina Sanjaya, 2008, Strategi Pembelajaran Berorientasi Standar Proses PendidikanJakarta: Kencana Prenada Media Group, 